\title{
People's Perception and Participation in Solid Waste Management in Ndokwa West Local Government Area, Delta State, Nigeria
}

\author{
Amukali Ogochukwu ${ }^{1, *}$, Bariweni Perekibina Anthony², Sophia Memuna John³, \\ Imaitor-Uku Ebinemi Edith ${ }^{4}$ \\ ${ }^{1}$ Department of Environmental Management, Niger Delta University, Wilberforce Island, Amassoma, Bayelsa State, Nigeria \\ ${ }^{2}$ Department of Marine Environment and Pollution Control, Nigeria Maritime University, Okerenkoko, Delta State, Nigeria \\ ${ }^{3}$ Department of Economics, Isaac Jasper Boro College of Education, Sagbama, Bayelsa State, Nigeria \\ ${ }^{4}$ Department of Geography, Isaac Jasper Boro College of Education, Sagbama, Bayelsa State, Nigeria
}

Email address:

amukaliogo@gmail.com (A. Ogochukwu)

${ }^{*}$ Corresponding author

\section{To cite this article:}

Amukali Ogochukwu, Bariweni Perekibina Anthony, Sophia Memuna John, Imaitor-Uku Ebinemi Edith. People's Perception and Participation in Solid Waste Management in Ndokwa West Local Government Area, Delta State, Nigeria. International Journal of Natural Resource Ecology and Management. Vol. 5, No. 3, 2020, pp. 108-114. doi: 10.11648/j.ijnrem.20200503.14

Received: May 26, 2020; Accepted: June 18, 2020; Published: August 19, 2020

\begin{abstract}
This work focused on assessing people's perception and participation in solid waste disposal, collection and management methods in Six (6) towns of Ndokwa West LGA, Delta State, Nigeria. It utilized structured questionnaire and face to face interviews for data generation. The sampled towns were Utagba-Ogbe, Ogume, Abbi, Emu, Onicha-Ukwuani and Utagba-Uno, respectively. It was observed that, irrespective of respondent's localities, most shops/offices and residential houses lacked approved waste collection bags/bins from authorized waste handlers from the Local Government, rather, some augmented with personal packing bags. Collected waste materials were reportedly disposed-off by road sides, into gutters (where available), streets, pits, abandoned buildings, undeveloped plots, or directly into ponds, rivers and streams. Majority of the respondents outside Utagba-Ogbe were unaware of the existence of any government-approved disposal sites around their communities. Although, some of the respondents adopted waste burning, knowledge of integrated solid waste management was observed to be generally low. Respondents were generally not happy with services of waste handlers in the area. The current waste handling strategy in the study area would have serious health and environmental concerns via engendering disease epidemic. The Local Government Authority should make deliberate efforts to seek better ways of enforcing efficient waste-to-wealth strategies to help sustainably solve the waste generation and disposal problems in the study area.
\end{abstract}

Keywords: Public Perception, Solid Wastes, Waste Disposal, Landfill, Dumpsites

\section{Introduction}

Solid Wastes have posed lots of health and environmental problems in most parts of the world, with Nigeria not an exception. If solid waste problems are not well tackled in a timely manner, it would degenerate into greater problems for humanity because of the inevitable continuity in the waste generation, disposal and management cycle. Solid waste generation is inevitable so long humans continue to live on planet earth because waste materials would always be generated through everyday living. Wastes go by different names; trash, garbage or rubbish. The composition and characteristics of solid wastes vary from municipality to municipality [1]. Municipal Solid wastes refer to wastes of different aetiological backgrounds and usually considered unwanted materials from a particular process or system, and meant to be discarded after use owing to their being considered not useful to that particular process or system. Solid waste management is associated with the control of the 
processes of generation, storage, collection, transfer, transport, processing and disposal of solid wastes in a manner that is in accordance with the best principles and practices of public health, economics, engineering, conservation, aesthetics and other environmental considerations and which is responsive to public attitude [2].

Solid wastes can be classified in a number of ways, or specifically on the bases of certain criteria; e.g. source, environmental risks, utility and physical properties [3], respectively. Solid wastes can also be classified on the basis of source to include: municipal solid wastes, industrial solid wastes, agricultural solid wastes, mining and mineral wastes, construction and demolition wastes, healthcare wastes, radioactive (nuclear) wastes as well as human and animal wastes [4]. However, municipal solid wastes seem to get more attention as its one of the most problematic and prevalent waste material in our everyday life. With evolution of the new paradigm shift towards waste-to-wealth initiative, municipal solid waste materials, when properly managed, have tendencies to become beneficial and not detrimental to humanity and the environment.

The emphasis now has shifted from wastes being dumped indiscriminately into the environment to that of being converted into energy and allied sources with the aim of serving humanity better. However, Nigerian wastes collection, disposal and management authorities have not taken advantage of the huge potentials the large piles of solid waste dumps presently in the Nigerian environment, presents. Most Nigerian Local Government authorities under whose auspices waste disposal lies are still battling with collection and disposal issues, rather than sustainably managing them. It has been observed that about $87 \%$ of Nigerians usually use unsanitary methods of solid waste disposal methods [5] and these constitute nuisance, ugly sight, produce unpleasant odour, and create a breeding ground for pests and diseases. These have led to attendant negative health and environmental effects. Indiscriminate solid waste disposal is actually a menace and embarrassment to the nation where heaps of refuse litter most parts of the city [5].

This work was conceived to assess people's perception and their involvement in generation, collection and management of solid waste materials in Ndokwa West Local Government Area of Delta State, Nigeria with a view to sustainably solving the hydra-headed solid waste problems in the study area.

\section{Methodology}

Study Area

Ndokwa West Local Government Area of Delta state consists of Six (6) major localities (towns); namely, Utagba-Ogbe (Kwale), Ogume, Onicha-Ukwuani, UtagbaUno, Abbi and Emu, respectively with Utagba-Ogbe (Kwale) as the Local Government Headquarters of the Local Government Area. It is situated between 5.71 ${ }^{\circ}$ North of latitude, $6.44^{\circ}$ East longitude and $126 \mathrm{~m}$ above sea level [6]. Average annual temperature ranges from $68^{\circ} \mathrm{F}$ to $89^{\circ} \mathrm{F}$ with rainy periods lasting about 11 months, usually from January $29^{\text {th }}$ to December, $22^{\text {nd }}$ every year [7]. The area consists of $816 \mathrm{~km}^{2}$ with human population within the study area estimated to be 150,024 as at the 2006 census and with annual growth rate of $2.9 \%$ [7]. In this study, communities sampled and number of questionnaires shared per community is as shown in Table 1 .

A total of Five Hundred and Sixty (560) respondents were sampled in this study (Table 1). This consisted of 107 respondents from Utagba-Ogbe which represented $19.1 \%$ of the entire respondents, 120 from Ogume accounting for $21.4 \%, 83$ respondents amounting to $14.8 \%$ from each from Emu and Onicha-Ukwuani, 51 respondents from Abbi amounting to $9.2 \%$ and 116 respondents from Utagba-Uno amounting to $20.7 \%$ of the respondents in this study (Table 1).

Respondents were randomly sampled in each of the communities based on availability during sampling and waste-consciousness, irrespective of their ability to understand English language or not. For those who could not understand English language, an interpreter was used to interpret for them. Waste-consciousness was measured by the respondents' abilities to emphasize that wastes, when not properly handled could pose health and environmental problems. Respondents included staffs of some registered/accredited waste handlers with the Local Government authority, staffs of the Local Government Authority, Shop owners, business premises owners and private households/residents.

Table 1. Communities sampled with number of Questionnaires shared.

\begin{tabular}{|c|c|c|c|c|}
\hline S/No & Town & Quarter & $\begin{array}{l}\text { No. of } \\
\text { questionnaire }\end{array}$ & $\begin{array}{l}\text { Community } \\
\text { Total }\end{array}$ \\
\hline \multirow[t]{6}{*}{1} & \multirow[t]{6}{*}{ Utagba-Ogbe } & Isumpe & $17(3.0 \%)$ & \multirow{6}{*}{$107(19.1 \%)$} \\
\hline & & Umusadege & $20(3.6 \%)$ & \\
\hline & & Umuseti & $20(3.6 \%)$ & \\
\hline & & Umusam & $17(3.0 \%)$ & \\
\hline & & Umusedeli & $16(2.9 \%)$ & \\
\hline & & Ogbe-ani & $17(3.0 \%)$ & \\
\hline \multirow[t]{7}{*}{2} & \multirow[t]{7}{*}{ Ogume } & Igbe & $17(3.0 \%)$ & \multirow{7}{*}{$120(21.4 \%)$} \\
\hline & & Ogbe-Ogume & $20(3.6 \%)$ & \\
\hline & & Utue & $17(3.0 \%)$ & \\
\hline & & Ogbole & $17(3.0 \%)$ & \\
\hline & & Ogbagu & $16(2.9 \%)$ & \\
\hline & & Obodugwa & $16(2.9 \%)$ & \\
\hline & & Umuchime & $17(3.0 \%)$ & \\
\hline \multirow[t]{5}{*}{3} & \multirow[t]{5}{*}{ Emu } & Emu-Uno & $17(3.0 \%)$ & \multirow{5}{*}{$83(14.8 \%)$} \\
\hline & & Emu-Ebendo & $17(3.0 \%)$ & \\
\hline & & Emu-Obodoeti & $16(2.9 \%)$ & \\
\hline & & Emu-Obiogo & $16(2.9 \%)$ & \\
\hline & & Emu-Iyasele & $17(3.0 \%)$ & \\
\hline \multirow[t]{3}{*}{4} & \multirow[t]{3}{*}{ Abbi } & Umia & $17(3.0 \%)$ & \multirow{3}{*}{$51(9.2 \%)$} \\
\hline & & Okwelle & $17(3.0 \%)$ & \\
\hline & & Elovie & $17(3.0 \%)$ & \\
\hline \multirow[t]{5}{*}{5} & \multirow[t]{5}{*}{ Onicha-Ukwuani } & Ike-Onicha & $17(3.0 \%)$ & \multirow{5}{*}{$83(14.8 \%)$} \\
\hline & & Ugiliamai & $16(2.9 \%)$ & \\
\hline & & Eweshi & $17(3.0 \%)$ & \\
\hline & & Amorji & $16(2.9 \%)$ & \\
\hline & & Ibabu & $17(3.0 \%)$ & \\
\hline
\end{tabular}




\begin{tabular}{lllll}
\hline S/No & Town & Quarter & $\begin{array}{l}\text { No. of } \\
\text { questionnaire }\end{array}$ & $\begin{array}{l}\text { Community } \\
\text { Total }\end{array}$ \\
\hline 6 & Utagba-Uno & Isumpe & $17(3.0 \%)$ & \\
& & Umusadege & $17(3.0 \%)$ & \\
& & Umuseti & $17(3.0 \%)$ & \\
& & Umusam & $17(3.0 \%)$ & $116(20.7 \%)$ \\
& Etua-Uno & $16(2.9 \%)$ & \\
& Ikilibi & $16(2.9 \%)$ & \\
& Umusedeli & $16(2.9 \%)$ & 560 \\
& Total & $560(99.8 \%)$ & $(100.0 \%)$ \\
\hline
\end{tabular}

This study was done by modifying the structured questionnaire in an earlier work [8]. Face-to-face interviews, review of secondary data and personal observations by the Researchers were used to complement information generated from the structured questionnaire in this study.

\section{Results and Discussion}

It was opined earlier that waste generation increased with population increase, thus making waste generation and management cycle a continuous one [4]. This view has been supported by a couple of other researchers $[9,10,11, \& 12]$ in separate studies. Waste generation and management problem can take several dimensions; gender-sensitiveness, age-related perspectives, people's perception about waste management options and strategies to mention but a few. It was in the light of the afore-mentioned factors that this study was conceived to authenticate their roles with respect to waste management.

Generally, as could be seen from Table 2, people's perception and involvement in waste management in this specific study has proven to be gender-biased. Waste generation, collection and disposal seemed to have been gender-sensitive as more males (56.4\%) than females $(43.6 \%)$ were encountered in this study. In addition, more males were encountered at households $(75.0 \%)$ and waste handlers $(15.2 \%)$ than respondents of the female folks while the female respondents were encountered more at shops/business premises $(40.6 \%)$ than in the male folks $(9.8 \%)$, respectively.

The huge gap between male and female involvement in waste management among waste handlers could be due to existential presence of certain non-compelling factors. This was indicative of the fact that disposal and general handling of wastes seemed more of a masculine than a feminine endeavour as it requires withstanding offensive odour and disgusting piles of trash. A female respondent interviewed in Umusadege of Utagba-Ogbe stated that women tended to consider more 'fashionable' jobs as waste handling jobs could make them feel dirty. This finding was consistent with an earlier work [3] where they established the existence of gender-sensitiveness in their study on solid waste disposal and management methods in Makurdi and its environs in Benue State, Nigeria. On the other hand, more females $(40.6 \%)$ than males $(9.8 \%)$ being encountered among shops/business premises could be because more females who were employed as Sales Attendants or Representatives in such business premises were vested with the responsibility of ensuring cleanliness within the vicinity of the business premises.

Table 2. Gender Characteristics of the Respondents.

\begin{tabular}{lllll}
\hline Respondent's Sex & Households & Shops/Business Premises & Waste Handlers & Total \\
\hline Male & $237(75.0 \%)$ & $31(9.8 \%)$ & $48(15.2 \%)$ & $316(56.4 \%)$ \\
Female & $141(57.8 \%)$ & $99(40.6 \%)$ & $4(1.6 \%)$ & $244(43.6 \%)$ \\
Total & $378(67.5 \%)$ & $130(23.2 \%)$ & $52(9.3 \%)$ & $560(100 \%)$ \\
\hline
\end{tabular}

\subsection{Possession of Waste Containers}

A cursory look at Table 2 above showed that majority of the respondents encountered in this study were drawn mainly from households $(67.5 \%)$ as compared to Shops/Business premises and Waste Handlers. It was also found that majority of those sampled did not possess waste containers $(82.5 \%)$ as compared to just $17.5 \%$ of the respondents who had access to accredited waste containers/packing bags within their vicinities (Table 3). The only exception to this observation was at Utagba-Ogbe where Shops/Business premises significantly showed higher possession of waste containers/packing bags $(6.3 \%)$ than those who didn't have access to waste containers/packing bags (1.4\%) respectively (Table 3). Revenue generation motives must have influenced more possession of waste containers/packing bags by Shops/Business premises as compared to households in Utagba-Ogbe.

Generally, more of the respondents being drawn from households than Shops/Business premises had shown that the
6 towns sampled in this study were predominantly residential than commercial or industrial towns. This view was supported by an earlier work which did show that in terms of landuse/landcover changes for this study area, that bare surfaces, forest vegetation, settlements and woodlands were gradually being replaced by marshlands, scattered cultivation, shrub lands as well as water bodies within the entire Ndokwa region [4]. The study went ahead to state that settlements were found to be getting more concentrated within specific geographical regions as revealed by imageries obtained for the area from 1975 to 2015, thus noticed to have witnessed tremendous growths in population and settlement area and these had led to increased amounts of wastes generated within the area. Ordinarily, all households and shops/business premises ought to have access to waste containers/packing bags. Rather, it was found that majority of the waste containers found with respondents in this study were not from the authorized waste handlers as people had to improvise for themselves with personalized waste containers/packing bags. The high proportion of respondents 
not having access to waste containers/packing bags as compared to the fewer numbers who had is not a good indication for effective waste management strategies within the study area.

It could be safely stated that waste handlers showed more preference for shops and business operators than the residential buildings in isolated instances as observed in this study (Table 3). This preferential treatment could be responsible for majority of the residential households in the study area expressing concern on the inadequacy of the level of promptness in evacuating solid waste materials and consequent disposal of the waste materials by the authorized waste handlers. This view had been reported by other researchers in similar scenarios in Benue State, Nigeria [3] and Uganda [13], respectively.

Table 3. Respondent's Perception about Possession of Waste Containers.

\begin{tabular}{lllll}
\hline Location of sample sites & \multicolumn{4}{l}{ Possession of Waste Containers } \\
\hline Sample sites & Parameters & Has Waste Containers & No Waste Containers & Total \\
\hline Utagba-Ogbe & Households & $19(3.4 \%)$ & $45(8.0 \%)$ & $64(11.4 \%)$ \\
& Shops/Business & $35(6.3 \%)$ & $8(1.4 \%)$ & $43(7.7 \%)$ \\
Ogume & Households & $2(0.4 \%)$ & $77(13.7 \%)$ & $79(14.1 \%)$ \\
& Shops/Business & $1(0.2 \%)$ & $40(7.1 \%)$ & $41(7.3 \%)$ \\
Emu & Households & $3(0.5 \%)$ & $46(8.2 \%)$ & $49(8.8 \%)$ \\
& Shops/Business & $2(0.4 \%)$ & $32(5.7 \%)$ & $34(6.1 \%)$ \\
Abbi & Households & $3(0.5 \%)$ & $25(4.5 \%)$ & $28(5.0 \%)$ \\
Onicha Ukwuani & Shops/Business & $4(0.7 \%)$ & $19(3.4 \%)$ & $23(4.1 \%)$ \\
\multirow{2}{*}{ Utagba-Uno } & Households & $8(1.4 \%)$ & $56(10.0 \%)$ & $64(11.4 \%)$ \\
& Shops/Business & $7(1.3 \%)$ & $12(2.1 \%)$ & $19(3.4 \%)$ \\
& Households & $8(1.4 \%)$ & $61(10.9 \%)$ & $69(12.3 \%)$ \\
& Shops/Business & $6(1.1 \%)$ & $41(7.3 \%)$ & $47(8.4 \%)$ \\
& Total & $98(17.5 \%)$ & $462(82.5 \%)$ & $560(100 \%)$ \\
\hline
\end{tabular}

\subsection{Sorting of Wastes}

Results documented in Table 4 showed that, irrespective of sampled sites and demographic characteristics, that overwhelming majority of the respondents did not find it worthy to sort their waste materials $(83.2 \%)$ into respective designations for ease of handling, rather, they just disposed it off into environments they found convenient for disposal of such wastes. Other authors have found similar scenarios in similar studies in different towns; Lagos in Nigeria [1, 2], Makurdi in Nigeria [3], Kira town in Uganda [13] and Owerri in Nigeria [15], respectively. The only exception was in Utagba-Ogbe, the Local Government Headquarter where higher number of participants sorted their wastes before disposal. Nearness to the seat of power and increased awareness by waste handlers must have influenced this scenario. This showed that waste sorting is not of any significance to the disposers and this could be responsible for waste scavengers scavenging waste dumps in search of waste materials of different aetiological backgrounds in the study area.

In addition, sorted waste materials encountered in this study consisted mainly of bottles/glass, hard plastics, polyethylene materials, papers, scrap metals and decomposable food wastes. It was also discovered that of all the waste materials sorted in the study area, decomposable food wastes were the most predominant. This could be due to the agrarian nature of many respondents and the predominantly residential settlement nature of the town. This finding was consistent with a study on waste categorization in Yenagoa Metropolis, Bayelsa State, Nigeria [8].

Table 4. Respondent's Perception about Sorting of Wastes in the study area.

\begin{tabular}{lllll}
\hline Location of sample sites & & Waste Sorting & \\
\hline Sample sites & Parameters & Wastes were sorted & Wastes not sorted & Total \\
\hline Utagba-Ogbe & Households & $33(5.9 \%)$ & $31(5.5 \%)$ & $64(11.4 \%)$ \\
& Shops/Business & $30(5.4 \%)$ & $13(2.3 \%)$ & $43(7.7 \%)$ \\
Ogume & Households & $4(0.7 \%)$ & $75(13.4 \%)$ & $79(14.1 \%)$ \\
& Shops/Business & $3(0.5 \%)$ & $38(6.8 \%)$ & $41(7.3 \%)$ \\
Emu & Households & $2(0.4 \%)$ & $47(8.4 \%)$ & $49(8.8 \%)$ \\
& Shops/Business & $5(0.9 \%)$ & $29(5.2 \%)$ & $34(6.1 \%)$ \\
Abbi & Households & $1(0.2 \%)$ & $27(4.8 \%)$ & $28(5.0 \%)$ \\
& Shops/Business & $3(0.5 \%)$ & $20(3.6 \%)$ & $23(4.1 \%)$ \\
Onicha Ukwuani) & Households & $3(0.7 \%)$ & $60(10.7 \%)$ & $64(11.4 \%)$ \\
Utagba-Uno & Shops/Business & $3(0.5 \%)$ & $16(2.9 \%)$ & $19(3.4 \%)$ \\
& Households & $2(0.4 \%)$ & $67(12.0 \%)$ & $69(12.3 \%)$ \\
& Shops/Business & $4(0.7 \%)$ & $43(7.7 \%)$ & $47(8.4 \%)$ \\
\end{tabular}




\subsection{Respondent's View of Waste Reduction Strategies in the Study Area}

Waste reduction revolves around strategies like reuse, reduce and recycle and theses help to minimize the amount of waste generated and consequently disposed-off into the environment [17]. In addition, it was observed from Table 5 that majority of the respondents $(71.3 \%)$ in this study opined that it was possible for them to reduce the quantity of wastes generated before disposing same into the environment as opposed to minority $(28.7 \%)$ that believed wastes could not be quantitatively minimized before disposal into the environment. This is evidence of increased waste management awareness within the study area by respondents.

Tables 5. Waste Reduction and Recycling Strategies.

\begin{tabular}{llll}
\hline Location of sample sites & & Waste Reduction Strategies & \\
\hline Sample sites & Parameters & Waste reduction possible & Not possible to reduce wastes \\
\hline Utagba-Ogbe & Households & $33(5.9 \%)$ & $31(5.5 \%)$ \\
& Shops/Business & $26(4.6 \%)$ & $17(3.0 \%)$ \\
Ogume & Households & $51(9.1 \%)$ & $28(5.0 \%)$ \\
& Shops/Business & $29(5.2 \%)$ & $12(2.1 \%)$ \\
Emu & Households & $34(6.1 \%)$ & $15(2.7 \%)$ \\
& Shops/Business & $27(4.8 \%)$ & $7(1.3 \%)$ \\
Abbi & Households & $21(3.7 \%)$ & $7(1.3 \%)$ \\
& Shops/Business & $19(3.4 \%)$ & $4(0.7 \%)$ \\
Onicha Ukwuani & $53(9.4 \%)$ & $11(2.0 \%)$ \\
& Households & $18(3.2 \%)$ & $1(0.2 \%)$ \\
Utagba-Uno & Shops/Business & $52(9.3 \%)$ & $17(3.0 \%)$ \\
& Households & $36(6.4 \%)$ & $11(2.0 \%)$ \\
& Shops/Business & $399(71.3 \%)$ & $161(28.7 \%)$ \\
\hline
\end{tabular}

However, despite the belief of most respondents on the possibility of waste reduction strategies, majority still expressed the belief that waste reduction should be the exclusive prerogative of respective waste management agencies of government, and not theirs'. In fact, an earlier study observed similar scenario in Makurdi and environs in Benue State, Nigeria where they observed that most residents lacked waste reduction strategies and waited on Government agencies to do same [3]. The only exception was in Utagba-Ogbe households where there was no significant difference between those who practiced waste reduction strategies and those who didn't. Majority of the households who insisted they practice waste reduction strategies opined that they did so by selling waste papers to tissue paper manufacturing companies and burning other wastes in open fields within the study areas.

The mentality of majority of the respondents centered on the belief that waste materials were 'useless' and must be discarded at all cost and as soon as possible. Knowledge about 'waste-to-wealth' strategies was relatively low within the study area as many respondents did not believe in waste reduction and recycling strategies. This could be due to lack of provisions of mechanized waste recycling gadgets in the study area as suggested by in a similar study [11], thus predisposing respondents to erroneous belief in outright disposal of such wastes into the environment. Furthermore, this same phenomenal belief was observed similar studies in Lagos, Lagos State [1] and Owerri, Imo State [15], both in Nigeria.

\subsection{Waste Disposal Strategies}

With respect to the various avenues and methods that respondents encountered in the study area disposed-off their waste materials, it was observed (Table 6) that majority of the respondents $(50.4 \%)$ preferred disposing their wastes directly onto adjoining landfills (pits or valleys) within their nearest vicinities. This trend had earlier been reported in a study in Makurdi and environs, Benue State [3] and Owerri, Imo State [15], both in Nigeria. Many of such pits were results of excavations from where sand was taken from, mainly for construction works. Similarly, majority of the respondents from households at Utagba-Ogbe, Ogume, Emu, Onicha-Ukwuani and Utagba-Uno towns preferred outright disposal onto landfills as compared to combustion in either open fields or locally-made incinerators for burning down their wastes, taking them to collection centers or other means, respectively. However, majority of the respondents from shops/Business premises in Utagba-Ogbe preferred collecting their wastes and keeping same at approved designated points for Waste Handlers to pick up and dispose them, properly.

Table 6. Waste Disposal Strategies in the study area.

\begin{tabular}{|c|c|c|c|c|c|c|}
\hline \multirow{2}{*}{ Sampled sites } & \multirow{2}{*}{ Parameters } & \multicolumn{4}{|c|}{ Disposal Site/Method } & \multirow{2}{*}{ Total } \\
\hline & & Incineration & Landfill & Collection Centre & Others & \\
\hline \multirow[t]{2}{*}{ Utagba-Ogbe } & Households & $9(1.6 \%)$ & $21(3.8 \%)$ & $29(5.2 \%)$ & $5(0.9 \%)$ & $64(11.4 \%)$ \\
\hline & Shops/Business & $3(0.5 \%)$ & $2(0.4 \%)$ & $34(6.1 \%)$ & $4(0.7 \%)$ & $43(7.7 \%)$ \\
\hline \multirow[t]{2}{*}{ Ogume } & Households & $32(5.7 \%)$ & $41(7.3 \%)$ & $0(0.0 \%)$ & $6(1.1 \%)$ & $79(14.1 \%)$ \\
\hline & Shops/Business & $21(3.8 \%)$ & $18(3.2 \%)$ & $1(0.2 \%)$ & $1(0.2 \%)$ & $41(7.3 \%)$ \\
\hline
\end{tabular}




\begin{tabular}{|c|c|c|c|c|c|c|}
\hline \multirow{2}{*}{ Sampled sites } & \multirow{2}{*}{ Parameters } & \multicolumn{4}{|c|}{ Disposal Site/Method } & \multirow{2}{*}{ Total } \\
\hline & & Incineration & Landfill & Collection Centre & Others & \\
\hline \multirow[t]{2}{*}{ Emu } & Households & $4(0.7 \%)$ & $43(7.7 \%)$ & $1(0.2 \%)$ & $1(0.2 \%)$ & $49(8.8 \%)$ \\
\hline & Shops/Business & $18(3.2 \%)$ & $9(1.6 \%)$ & $4(0.7 \%)$ & $3(0.5 \%)$ & $34(6.1 \%)$ \\
\hline \multirow[t]{2}{*}{ Abbi } & Households & $22(3.9 \%)$ & $4(0.7 \%)$ & $1(0.2 \%)$ & $1(0.2 \%)$ & $28(5.0 \%)$ \\
\hline & Shops/Business & $5(0.9 \%)$ & $12(2.1 \%)$ & $4(0.7 \%)$ & $2(0.4 \%)$ & $23(4.1 \%)$ \\
\hline \multirow[t]{2}{*}{ Onicha Ukwuani } & Households & $15(2.7 \%)$ & $36(6.4 \%)$ & $11(2.0 \%)$ & $2(0.4 \%)$ & $64(11.4 \%)$ \\
\hline & Shops/Business & $12(2.1 \%)$ & $4(0.7 \%)$ & $1(0.2 \%)$ & $2(0.4 \%)$ & $19(3.4 \%)$ \\
\hline \multirow{2}{*}{ Utagba-Uno } & Shops/Business & $2(0.4 \%)$ & $39(7.0 \%)$ & $4(0.7 \%)$ & $2(0.4 \%)$ & $47(8.4 \%)$ \\
\hline & Total & $151(26.9 \%)$ & $282(50.4 \%)$ & $91(16.3 \%)$ & $36(6.4 \%)$ & $560(100.0 \%)$ \\
\hline
\end{tabular}

Table 7. Frequency of Waste Collection by Waste Collection Agencies.

\begin{tabular}{|c|c|c|c|c|c|c|c|}
\hline Sampledsites & Parameters & Daily & Weekly & Biweekly & Monthly & No idea & Total \\
\hline \multirow[t]{2}{*}{ Utagba-Ogbe } & Households & $0(0.0 \%)$ & $32(5.7 \%)$ & $2(0.4 \%)$ & $0(0.0 \%)$ & $30(5.4 \%)$ & $64(11.4 \%)$ \\
\hline & Shops/Business & $0(0.0 \%)$ & $36(6.4 \%)$ & $0(0.0 \%)$ & $0(0.0 \%)$ & $7(1.3 \%)$ & $43(7.7 \%)$ \\
\hline \multirow[t]{2}{*}{ Ogume } & Households & $0(0.0 \%)$ & $2(0.4 \%)$ & $1(0.2 \%)$ & $0(0.0 \%)$ & $76(13.6 \%)$ & $79(14.1 \%)$ \\
\hline & Shops/Business & $0(0.0 \%)$ & $1(0.2 \%)$ & $0(0.0 \%)$ & $0(0.0 \%)$ & $40(7.1 \%)$ & $41(7.3 \%)$ \\
\hline \multirow[t]{2}{*}{ Emu } & Households & $0(0.0 \%)$ & $2(0.4 \%)$ & $0(0.0 \%)$ & $0(0.0 \%)$ & $47(8.4 \%)$ & $49(8.8 \%)$ \\
\hline & Shops/Business & $0(0.0 \%)$ & $3(0.5 \%)$ & $0(0.0 \%)$ & $0(0.0 \%)$ & $31(5.5 \%)$ & $34(6.1 \%)$ \\
\hline Abbi & Households & $0(0.0 \%)$ & $1(0.2 \%)$ & $2(0.4 \%)$ & $0(0.0 \%)$ & $25(4.5 \%)$ & $28(5.0 \%)$ \\
\hline \multirow[t]{2}{*}{ Onicha Ukwuani } & Households & $0(0.0 \%)$ & $11(2.0 \%)$ & $2(0.4 \%)$ & $0(0.0 \%)$ & $51(9.1 \%)$ & $64(11.4 \%)$ \\
\hline & Shops/Business & $0(0.0 \%)$ & $1(0.2 \%)$ & $0(0.0 \%)$ & $0(0.0 \%)$ & $18(3.2 \%)$ & $19(3.4 \%)$ \\
\hline \multirow[t]{3}{*}{ Utagba-Uno } & Households & $0(0.0 \%)$ & $2(0.4 \%)$ & $5(0.9 \%)$ & $1(0.2 \%)$ & $61(10.9 \%)$ & $69(12.3 \%)$ \\
\hline & Shops/Business & $0(0.0 \%)$ & $3(0.5 \%)$ & $0(0.0 \%)$ & $0(0.0 \%)$ & $44(7.9 \%)$ & $47(8.4 \%)$ \\
\hline & Total & $0(0.0 \%)$ & $97(17.3 \%)$ & $12(2.1 \%)$ & $1(0.2 \%)$ & $450(80.4 \%)$ & $560(100.0 \%)$ \\
\hline
\end{tabular}

As could be seen from Table 7, the approved and accredited waste collection agencies seemed not to have visited collection points on daily bases $(0.0 \%)$, rarely visited on biweekly $(2.1 \%)$ and monthly $(0.2 \%)$, and more frequent on weekly bases $(17.3 \%)$, even though the frequency of repeated visits were low. The frequency of visit was considerably higher in Utagba-Ogbe than in other towns sampled in this study. This could be due to the fact that Utagba-Ogbe is the Headquarter of the Local Government under whose jurisdiction laid the responsibility for waste management in the entire study area. In addition, Table 7 above showed that there was very little presence of the waste handling agencies in communities like Ogume, Emu, Abbi, Onicha-Ukwuani and Utagba-Uno, respectively.

It was also observed that none of the respondents agreed to have seen waste collection agencies within their vicinities with intention of daily collection of wastes for eventual disposal in designated sites. This could be held accountable for the huge and disgusting refuse dumps occasionally seen around refuse collection sites and outskirts of the towns in the study area. Weekly refuse collection was also reported by several researchers in different towns; Lagos, Nigeria [1], Makurdi and environs, Nigeria [3] and Benin City, Nigeria [17]. Practices like these cause dissatisfaction in service delivery. No wonder it was reported that less than $60 \%$ of municipal solid wastes generated were collected in developing countries because solid waste generation exceeded collection capacity [11]. The need for better solid waste management remains paramount in developing countries.

Table 8. Major Method of Municipal Waste Management in Kwale.

\begin{tabular}{llllllll}
\hline Waste Handler & Burning & Burying & Composting & Reduction & Dumping & Reuse \\
\hline A & Yes & No & No & No & Yes & Yes \\
B & Yes & No & No & No & Yes & Yes \\
C & Yes & Yes & No & Yes & Yes & Yes \\
\hline
\end{tabular}

Only Three (3) accredited Waste Handlers were accessibly recognized and sampled in this study (Table 8). It was observed that all 3 Waste Handlers dumped collected waste materials upon open dump sites like pits or valleys in outskirts of the towns prior to collection. They all agreed that they never meant to just dump wastes in open dumps but that the intention was to dump and burn. They also stated that their inability to burn them out rightly was because many of such wastes were collected very wet, hence non-combustible as at dumping time. This was in line with the work of an earlier study on waste levels and assessment of their current management strategies in the Yenagoa Metropolis which revealed that domestic wastes from their specific study consisted mainly of wet and non-combustible materials [8]. This meant that the period between dumping and waiting for the waste materials to dry up accounted for the huge disgusting and smelly refuse dumps seen dumped at the outskirts of the towns of the study area. This was further complicated by rains during rainy season as the study area usually experiences up to 11 months of rain per year [6]. Furthermore, none of the Waste Handlers carried out composting or injection irrespective of the nature and 
composition of the wastes collected.

\section{Conclusions}

It has been observed through this work that a lot needs to be done with the waste generation, collection and management systems in the towns that make up Ndokwa West Local Government Area in Delta State, Nigeria. It was noticed that many residents though lacked the Governmentapproved refuse packing containers; they possessed selfmade waste containers/packing bags for collection and disposal of such wastes. The adopted methods of solid waste collection, disposal and overall management in the study area could be said not to be appropriate as the weekly collection period for wastes in the study area is grossly in adequate and cannot effectively solve the hydra-headed waste collection and disposal problems in the study area. A situation where the waste materials were collected and dumped at open dumpsites irrespective of their characteristic composition and nature is an unfriendly environmental practice as it could lead to seepage of heavy metals into soils of the study area. Open dumping and burning as practiced in the study area were not effective means of disposing all classes of wastes, especially those containing toxic heavy metals in them.

It is therefore being advocated that the Waste Handlers should be empowered enough and trained to acquire the capacity and expertise to execute unique strategies like injection, burying and a host of other strategies, other than just open dumping and burning. Towns like Ogume, Emu, Abbi, Onicha-Ukwuani and Utagba-Uno should be properly incorporated into the Local Government's waste management architecture as that is currently lacking. The Waste Handlers should be made to be evacuating wastes on daily basis and not weekly as is being currently practiced in the study area. Core Environmentalists should be involved in waste management business in the study area so that they could bring their expertise and technological know-how into practice so as to enhance sustainable waste management in the study area.

\section{References}

[1] Adewole, A. T. (2009) Waste Management towards Sustainable Development in Nigeria: A case study of Lagos State. International NGO Journal. 4 (4): 173-179.

[2] Agbesola, Y. O. (2013) Sustainability of Municipal Solid Waste Management in Nigeria: A case study of Lagos. An M.Sc Thesis in Water and Environment Sciences, Department of Thematic Studies Linkoping Universitat.

[3] Aguoru, C. U. and Alu, C. A. (2015) Studies on Solid Waste Disposal and Management Methods in Makurdi and its Environs, North Central Nigeria. Greener Journal of Environmental Management and Public Safety, 4 (2): 019027.
[4] Amukali, O., Imaitor-Uku, E. E., Obadoni, B. O. and Inainfe, N. (2018) Effects of Human and Natural Activities on Land Cover Changes in Kwale Region, Delta State, Nigeria. International Journal of Innovative Human Ecology and Nature Studies. 6 (1): 6-13.

[5] Amukali, O. (2019) Effects of Wastes from Auto-mechanic Workshops on Concentrations of Heavy Metals in Soils and Plants in Yenagoa Metropolis, Nigeria. A Ph.D Dissertation submitted to The Post Graduate School of Niger Delta University, Amassoma, Bayelsa State, Nigeria. 278p.

[6] Anonymous (2016) Average Weather in Kwale, Nigeria. Available at https://weatherspark.com. Downloaded on $14^{\text {th }}$ August, 2018.

[7] Anonymous (2018) Map of Kwale, Delta State-Road Map, Satellite View and Street View. Available at https://MapsStreetView.com. Updated on Tuesday, $7^{\text {th }}$ August, 2018 and downloaded $14^{\text {th }}$ August, 2018.

[8] Bariweni, P. A., Izonfuo, W. L. and Amadi, E. N. (2002) Domestic Waste Levels and Assessment of their Current Management Strategies in Yenagoa Metropolis. Global Journal of Environmental Sciences. 1 (1): 15-19.

[9] Bhatia, H. (2010) Water Pollution in the Chemical Industries. John Welsh Publications, India. Pp. 35-658.

[10] Blanche, T., Martin, Durrheim, K. and Desmond, P. (2006) Research in Practice: Applied Methods for the Social Sciences, Cape Town, University of Cape Town Press.

[11] Isu, B. A. (2005) The Pains of Waste. A Paper Presented at the Workshop Organized by Committee on Vital Environmental Resources for Teachers/Students, Eghosa Anglican Grammar School, Benin City, 1-6 pp.

[12] Kumar, S., Dhar, H., Nair, V. V., Bhattacharyya, J. K., Vaidya, A. N. and Akolka, A. B. (2016) Characterization of Municipal Solid Waste in High-Altitude Sub-Tropical Regions. Environmental Technology. 37: 2627-2637.

[13] Mukisa, P. K. (2009) Public Participation in Solid Waste Management: Challenges and Prospects. A Case of Kira Town Council, Uganda.

[14] National Bureau of Statistics (2017) Delta State in Nigeria. Available at $h t t p: / / w w w . c i t y p o p u l a t i o n . d e / p h p$

[15] Nkwocha, E. E., Pat-Mbano, E. C. and Dike, M. U. (2011) Evaluating the Efficiency of Solid Waste collection Services in Owerri Municipality, Nigeria. International Journal of Science and Nature, 2 (1): 89-95.

[16] Ogwueleka, T. (2009) Municipal Solid Waste Characteristics and Management in Nigeria. Iranian Journal of Environmental Health, Science and Engineering, 6 (3): 173180.

[17] Omofonmwan, S. I. and Eseigbe, J. O. (2009) Effects of Solid Waste on the Quality of underground Water in Benin Metropolis, Nigerian Journal of Human Eco., 26 (2): 99-105.

[18] Tchobanoglous, G., Theisen, H. and Vigil, S. (1993) Integrated Solid Waste Management. McGrow Hillm Series, p. 7. 